\title{
Where are Western Bounds of Area S. h. minussensis?
}

\author{
Mikhail G. Golovatin ${ }^{1, *}$ and Sergey P. Paskhalny ${ }^{2}$
}

\author{
${ }^{1}$ Institute of Plant and Animal Ecology, Ural Branch of Russian Academy of Sciences, 620144, 8 March str., Ekaterin- \\ burg, Russia; ${ }^{2}$ Ecological Research Station, Institute of Plant and Animal Ecology, Ural Branch of Russian Academy of \\ Sciences, 620400, Zelenaya Gorka, 18-1, Yamal-Nenets Autonomous area, Russia
}

\begin{abstract}
We reported about several common terns with dark bill (subspecies Sterna hirundo minussensis and $S$. $h$. longipennis) in the Lower Ob region of Western Siberia, including nesting of the Central Siberian tern here. The ratio of terns with a dark bill and nominate color was about 8 to 1 . Our findings change the previous understanding of areas of the distribution of those subspecies.
\end{abstract}

Keywords: Area, common tern, distribution, lower Ob, Sterna hirundo minussensis, S. h. longipennis.

\section{INTRODUCTION}

Four subspecies of the Common Tern are generally recognized [1,2]: Nominate S. h. hirundo (Linnaeus, 1758), Central Siberian S. h. minussensis (Sushkin 1925), Eastern S. h. longipennis (Nordmann, 1835) and Tibetian (Saunders, 1876). These subspecies are well distinguished by the color of the bill, so $S$. $h$. longipennis and $S$. $h$. hirundo are similar to each other even less than they and the Arctic tern S. paradisaea are. However, S. h. minussensis, which is intermediate in bill color, is often regarded as a hybrid between $S$. $h$. longipennis and $S$. h. hirundo [3-6]. Even if to consider $S . h$. minussensis both as an intergrade and as morphs or race, an information about distribution of this form is interesting in understanding the intraspecific differentiation of common tern.

In the last decade there have been reports about vagrant dark-billed Common terns $(S . h . \quad$ minussensis and S. h. longipennis) in Europe. For example, V. Sotnikov had observed a single bird $S$. h. minussensis in a colony of nominate tern in the Kirov region of European part of Russia $\left(58^{\circ}\right.$ $25^{\prime} \mathrm{N}, 50^{\circ} 27^{\prime} \mathrm{E}$ ) [7]. Vagrant dark-billed Common tern was recorded even in England [8]. However, ornithologists and bird watchers still believe that dark-billed terns reside in Central and Eastern Siberia. This is because current descriptions of areas occupied by of those subspecies of the Common Tern are based on the handbook "Birds of Soviet Union" [3]. Distribution map from this classic volume has been copied into many other books, including modern publications. According to Dementiev and Gladkov [3] S. h. hirundo is found so far east as to the Yenisei River, where its area abuts $S$. h. minussensis and S. h. longipennis near the confluence of mouth of the Yenisei and Nizhnyaya Tunguska Rrivers (about $65^{\circ} 51^{\prime}$ N, $88^{\circ} 23^{\prime}$ E; Fig. 1). Middle and Lower $\mathrm{Ob}$ was part of area of the Nominate common tern, and this was confirmed by previous observations.

*Address correspondence to this author at the Institute of Plant and Animal Ecology, Ural Branch of Russian Academy of Sciences, 620144, 8 March str., Ekaterinburg, Russia; Tel: +7 9221024289; Fax: +7(343)2606500;

E-mail: golovatin@yandex.ru
The first detailed description of the avifauna of the Lower Ob River floodplain was published in 1898 by Konstantin M. Deriugin [9]. After that, there were only small fragmentary observations in 1915, 1921, 1959 [10-12]. Next thorough research of the avifauna was in 1962, 1963 by Nikolay N. Danilov [13]. Thereafter, the flow of information about birds of Lower Ob floodplain, especially near Labitnangi and Salekhard towns, become regular [14]. Since 2004, our annual thorough investigations of the avifauna of the Lower Ob River floodplain are continued. However, until 2008, researchers do not even mention the dark-billed Common terns here. And this despite the fact that Common tern is a usual species in the floodplain of the Lower Ob [14].

Finds of black-billed terns since 2008 have made this a special study to assess the present part of this form among Common terns here. The aim of this publication is to state the changes occurring in area of S.h. minussensis.

\section{STUDY AREA AND METHODS}

Our study covered the territory of the Lower Ob downstream $64^{\circ} 33^{\prime} \mathrm{N}, 65^{\circ} 16^{\prime} \mathrm{E}$ down to estuary. We made observations with binoculars while traveling on a ship and special excursions along small channels on a motorboat. In 2012 , we explored flood-plain down to $66^{\circ} 43^{\prime} \mathrm{N}, 68^{\circ} 07^{\prime} \mathrm{E}$. That is about $330 \mathrm{~km}$ along flood-plain of the Ob. Our work took place during the period 18 June -10 July and $20-26$ July. In 2013, we explored flood-plain downstream Arctic Circle to estuary. That is about $240 \mathrm{~km}$ along flood-plain of the Ob. The work was carried out from 25th June to 4th July. To find out the ratio of dark-billed and red-billed Common terns, we paid close attention to only those birds whose bill color was seen clearly. The individuals were observed at close distance (up to $30 \mathrm{~m}$ ) with well-lit (direct lighting, and not against the light). Despite the fact that we found $S$. h. longipennis, in the identification of dark-billed terns we did not distinguish between S.h. longipennis and $S$. h. minussensis. In addition, we had been looking through our photos of Common terns in the Lower $\mathrm{Ob}$ region from over previous years of observation. 


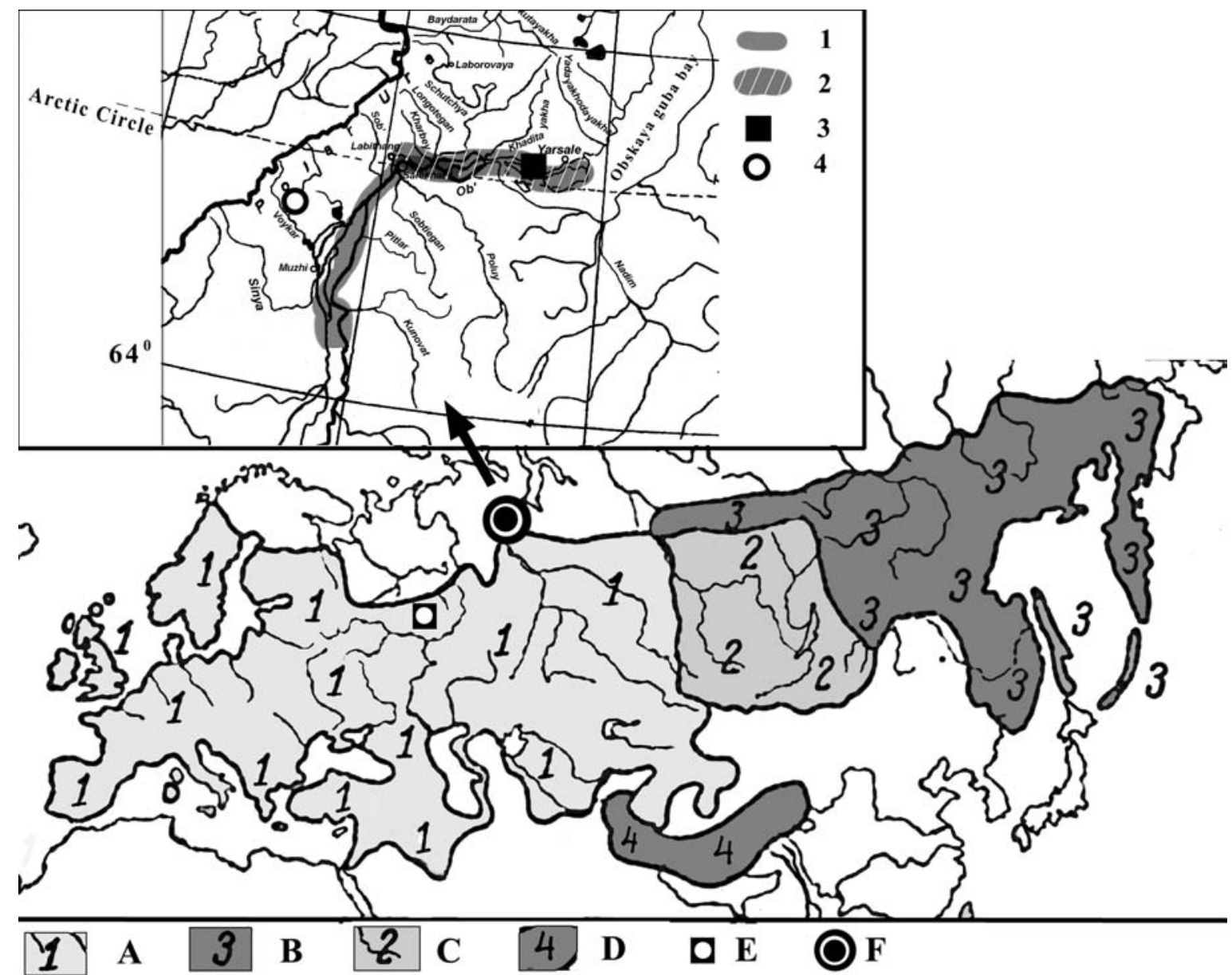

Fig. (1). Distribution map of Common Tern subspecies in Eurasia (by Dementiev 1951): A - S. h. hirundo, B - S. h. lomgipennis, C - S. h. minussensis, D - S. h. tibetiana, E - point of occurrence of $S$. h. minussensis in East European part of Russia (by Sotnikov 2002), F - area of our study. In marginal map: 1 - The area covered by our study in 2012; 2 - The area covered by our study in 2013; 3 - the most northern point of finding of $S$. h. minussensis; 4 - the most western point of finding of $S$. $h$. minussensis. Photo 1). Subspecies of the Common Tern in flood-

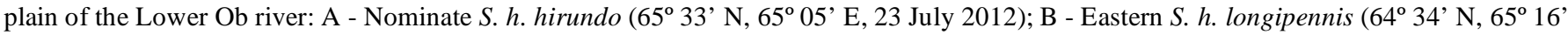
E; 21 June 2012). Photo 2). Central Siberian Common Tern S. h. minussensis and its nest in the vicinity of Labytnangi town $\left(66^{\circ} 39^{\prime} \mathrm{N}^{\prime}, 66^{\circ}\right.$ $32^{\prime}$ E, 4 July 2009). Photo 3). Common Tern with completely black bill and red legs (probably S. h. minussensis) in Upper Voikar river $\left(66^{\circ} 01^{\prime} \mathrm{N}, 63^{\circ} 44^{\prime} \mathrm{E} ; 15.06 .2008\right)$.

The total length of channels, where there have been observations of terns, and also number of registered terns and individuals with identified color of bills are presented on the (Table 1).

Table 1. The Total Length of Way (channels) with Observations of Terns (L), Number of Common Terns, Registered (N) and with Identified Bills (n).

\begin{tabular}{|c|c|c|c|c|}
\hline \multirow{2}{*}{ Year } & Area & L & N & n \\
\hline \hline \multirow{2}{*}{2012} & to south of the Arctic Circle & 575 & 551 & 95 \\
\cline { 2 - 5 } & to north of the Arctic Circle & 135 & 100 & 13 \\
\hline \multirow{2}{*}{2013} & to north of the Arctic Circle & 255 & 68 & 12 \\
\hline
\end{tabular}

The total way length of the observations was $575 \mathrm{~km}$ south of the Arctic Circle and $390 \mathrm{~km}$ north of it. In 2012, a total of 651 Common terns were registered and in $2013-68$.
In 2012, the respective percentages of terns with identified color of bill were $17,2 \%$ on the south and $13,0 \%$ in the north of the Arctic Circle, in 2013 - 17,6\%. Since on the north the annual numbers of identified birds were not large, to increase the sample size, we combined data from both years.

Confidence intervals of proportion and comparison of proportions of dark-billed terns to the south and to the north of the Arctic Circle were calculated by Fisher test.

\section{RESULTS}

In the Lower $\mathrm{Ob}$ region, we found Common terns with bill color typical of all three subspecies: the Nominate - red bill with a black tip and the red legs, the Central Siberian black upper mandible with a hint of red on the lower mandible and red legs, and the Eastern - completely black bill and dark red legs (photos 1-3). In the vicinity of Labytnangi town $\left(66^{\circ} 39^{\prime} \mathrm{N}, 66^{\circ} 32^{\prime} \mathrm{E}\right)$, a solitary nest of $S$. h. minussensis was found on 4th July 2009 on the open sandy wasteland 
of anthropogenic origin. The bird was incubating three eggs (photo 2). In Lower Ob, the northernmost point of finding of $S$. h. minussensis was $66^{\circ} 43^{\prime} 41^{\prime \prime} \mathrm{N}, 70^{\circ} 20^{\prime} 34^{\prime \prime}$ E. Also we observed Common Tern with a completely dark bill (but red legs) in the foothills of the Polar Urals $\left(66^{\circ} 01^{\prime} \mathrm{N}, 63^{\circ} 44^{\prime} \mathrm{E}\right)$, that was distant from the Ob River floodplain (photo 3 ). This was the most western point of finding of the dark-billed terns in this region.

In the Lower $\mathrm{Ob}$, Common terns were more numerous south of the Arctic Circle, as compared with the northern part. Their frequency of occurrence here was $0.96 \pm 0.04$ and in the north $0.43 \pm 0.03$ ind./km channels $(\mathrm{SE}=\sqrt{ } \mathrm{N}$, from: $[15$, 16]).

Percentage of dark-billed birds was 88.4 (81,3-94,0\%, $F$ test) on the south and $68.0(48,8-84,4 \%, F$-test $)$ in the north of this region. The difference between these proportions is significant ( $\mathrm{p} \leq 0.05 ; \mathrm{U}=2.26, F$-test).

\section{DISCUSSION}

The emergence of a lot of dark-billed Common terns in the Lower $\mathrm{Ob}$ in recent years, in the absence of records about them in previous years suggests that this form was really absent in this region. Otherwise, any of ornithologists still would have noticed it. Thus, now the western boundary on the north of the area $S$. $h$. minussensis may be drawn along the Lower $\mathrm{Ob}$, more precisely on $63^{\circ} 44^{\prime}-66^{\circ} 32^{\prime} \mathrm{E}$. The extreme northern point here may be specified as $66^{\circ} 43^{\prime} 41^{\prime \prime}$ $\mathrm{N}$. That is, this boundary is very close to the border between Europe and Asia.

If a datum point is taken 1925 - year of description subspecies, it may be said that during 83 years the bound of area of Central Siberian tern shifted nearly $1100 \mathrm{~km}$ to the west. Although this process was probably faster - in a shorter time. In all probabilities, Central Siberian tern S. h. minussensis may be seen as one of the examples of the long-standing process of promoting the Siberian species in the north-west, equally with such species as Pintail snipe Gallinago stenura, Arctic warbler Phylloscopus borealis, Bluetail Tarsiger cyanurus, Olive-backed Pipit Anthus hodgsoni, Petchora pipit Anthus gustavi, Pallas's Reed Bunting Emberiza pallasi and others [17, 18].

It should be noted, however, that in the Lower Ob region the expansion of $S$. $h$. minussensis has been accompanied by a reduction in the number of birds of nominate Common tern $S$. $h$. hirundo. According to our observations, the ratio of dark-billed to nominate terns was about 8 to 1 on the south and about 2 to 1 on the north of the Arctic Circle. Though the total number of Common Terns remained the same about 1 ind./ km channels [14]. Consequently, it may well be that nominate race has been absorbed by eastern races. For more accurate conclusions, genetic studies are needed.

\section{CONFLICT OF INTEREST}

The author(s) confirm that this article content has no conflicts of interest.

\section{ACKNOWLEDGEMENT}

The study was supported by Programs of the Presidium of the Ural Branch of the Russian Academy of Sciences № 12-M-45-2062 and № 12-4-012-3-ARCTIC.

\section{REFERENCES}

[1] Harrison P. Seabirds, an identification guide. Boston: Houghton Miflin Co. 1983.

[2] Koblik EA, Red'kin YaA, Arhipov VYu. Check-list of birds of the Russian Federation. Moscow: KMK 2006.

[3] Dementiev GP. Order Gulls In: Dementiev GP, Gladkov NA, Eds. Birds of Soviet Union. Moscow, Soviet Science 1951: vol. III: pp. 372-603.

[4] Vaurie Ch. The birds of the Palearctic fauna. Non-Passeriformes London: H.F. and G. Witherby vol. 1: 1965.

[5] Cramp S, Brooks DJ, Dunn E, et al. Handbook of the birds of Europe, the Middle East, and North Africa: the birds of the Western Palearctic. vol. IV. Terns to Woodpeckers. Oxford; London. New York: Oxford University Press 1985.

[6] Olsen KM, Larsson H. Terns of Europe and North America. Princeton, NJ: Princeton University Press 1995.

[7] Sotnikov VN. Birds of the Kirov region and adjacent areas. vol. 1: Non-Passeriformes. Part 2. Kirov: OOO “Triada-S” 2002.

[8] Nixon S. The Eastern Common Tern in Suffolk. Birding World 2011; 24 (5): 211-5.

[9] Deryugin KM. Journey to the valley of the middle and lower reaches of the $\mathrm{Ob}$ river and fauna of this area. Proceedings of the St. Petersburg Society of naturalists. Branch Zool Physiol 1898; 39 (2): 47-140.

[10] Shuhov IN. Birds of Obdorsk land. Year book. Zool Muse Imperia Acad Sci 1915; 20 (2): 167-238.

[11] Shostak AS. Ornithological observations in summer 1920 (Tomsk - Trekhbugorny cape - Krugly cape). Bull Tomsk Ornithol Soc 1921; 1: 105-14.

[12] Dobrinsky LN. Data about northern bound of distribution of some species of birds in the territory Yamal-Nenets national okrug. Materials on fauna of the North Priob'ye and its use. Proceedings of the Salekhard station of the Ural Branch of Academy of Sciences of USSR. Issue 1. Tiumen: Tiumen Book Press 1959; pp. 367-84.

[13] Danilov NN. Birds of the Lower Ob and the changes in their distribution over the last decade. Proceedings of the Institute of Biology, Ural branch of the Academy of Sciences USSR 38: Ecology of vertebrate animals of the Far North 1965; pp. 103-9.

[14] Golovatin MG, Paskhalny SP. Avifauna of Lower Ob flood-plain. Scientific Bulletin 4: Materials to the knowledge of the fauna and flora of the Yamal-Nenets Autonomous District (Part 1). Salekhard 2000; pp. 18-37.

[15] Smirnov VS. Methods of census mammals. Prerequisites for their improvement and evaluation of the accuracy for the results of the census. Sverdlovsk: Middle Urals book Press 1964.

[16] Järvinen O, Väisänen RA. Confidence limits for estimates of population density in line transects. Ornis Scand 1983; 14: 129-34.

[17] Golovatin MG, Morozova LM, Ektova SN, Paskhalny SP. The change of tundra biota at Yamal peninsula (the North of the Western Siberia, Russia) in connection with anthropogenic and climatic shifts. In: Gutierrez B, Pena C. Eds, Tundras: Vegetation, Wildlife and Climate trends. New York: Nova Science Publishers Inc. 2010: pp. 1-46.

[18] Golovatin MG. Modern aspects of the dynamics of the avifauna north of Western Siberia. In: Matishov GG, Tishkov AA, Ed. Terrestrial and marine ecosystems. Moscow: Saint-Petersburg, Paulsen Editions 2011: pp. 365-78.

\footnotetext{
Received: June 24, 2013

Revised: November 13, 2013

Accepted: November 18, 2013

(C) Golovatin and Paskhalny; Licensee Bentham Open.

This is an open access article licensed under the terms of the Creative Commons Attribution Non-Commercial License (http://creativecommons.org/licenses/by-nc/3.0/) which permits unrestricted, non-commercial use, distribution and reproduction in any medium, provided the work is properly cited.
} 